doi: $10.3935 /$ rsp.v22i2.1278

\section{SOCIAL HOUSING IN TRANSITION COUNTRIES}

\section{Jozsef Hegedus, Martin Lux, Nora Teller (eds.)}

New York, NY, USA, Oxon, UK: Routledge, 2013., 342 str.

U ovoj knjizi predstavljeni su doprinosi eminentnih istraživača iz područja stambenih politika na temu socijalnog stanovanja posttranzicijskih zemalja Istočne i Srednje Europe. Knjiga se sastoji od predgovora, zahvala, četiri zasebna dijela knjige s ukupno 19 poglavlja, bilješki o autorima te indeksom pojmova.

Sadržaj prvog dijela knjige odnosi se na uvodno poglavlje Jozsefa Hegedusa Transformacija socijalnog stambenog sektora u Istočnoj Europi: konceptualni okvir. Radikalna tranzicija postsocijalističkih zemalja 1990-ih, u području stanovanja očitovala se demontažom tzv. »istočnoeuropskog stambenog modela «, odnosno, »jednopartijske političke kontrole nad stambenim sektorom, podređene uloge tržišnih mehanizama, manjka tržišnog natjecanja među stambenim agencijama (birokratska koordinacija), i široke kontrole nad alokacijom stambenih usluga (velike, netransparentne subvencije)« (str. 6). Postojanje podmodela autor objašnjava odabirom različitih »policy opcija « pojedinih vlada. Primjerice, jugoslavenski i mađarski modeli podrazumijevali su prešutnu toleranciju vlasti prema postojanju neformalnog stambenog sektora i »kvazi-tržišnih mehanizama«, dok su ruske, bugarske $i$ istočnonjemačke vlasti odgovarale na manjak stanova, uzrokovan netržišnim (političkim) »alokacijama prema zaslugama«, još strožim kontrolnim me- hanizmima. Na deklaratornoj razini, koncept socijalnog stanovanja nije postojao. Državno-kontrolirani javno-najamni sektor pojavljivao se, ovisno o pojedinoj državi, u raznim oblicima: »stambeni fond državnih poduzeća (npr. radnički hosteli), stambeni fond lokalnih vlasti, i najamni fond pod zajedničkom kontrolom lokalnih vlasti i državnih poduzeća« (str. 7). Također, autor navodi i kategoriju »vezane akomodacije« - stanovanja osiguranog na temelju određene vrste zaposlenja poput policije i vojske sa snažnim stanarskim pravima koja su uključivala i pravo na razmjenu, nasljeđivanje te čak i svojevrsnu prodaju. Sustavna tranzicijska reforma nastupila je prema diktatu Svjetske banke nakon 1993. godine, u svrhu približavanja idealnom stambenom modelu u kojem »tržišni mehanizmi dominiraju stambenom proizvodnjom, alokacijom i potrošnjom; postoji dovoljno natjecanje između agenata $\mathrm{i}$ institucija $\mathrm{u}$ međusobno povezanim tržištima stambenih financija, resursa i usluga; vlade pružaju transparentne, progresivno usmjerene subvencije financirane na održive načine« (str. 10). Autorova ocjena tranzicijskih (ne) uspjeha temelji se na odbacivanju pojednostavljenog linearnog modela objašnjenja problematizirajući strategije »uspostave« i »ispravljanja《 tržišta te »čimbenike političke statike«. Zaključnom mišlju, postavljen je konceptualni okvir svih nadolazećih studija u zborniku: »izazov stambene politike $\mathrm{u}$ tranzicijskim zemljama jest osiguravanje institucionalne pomoći društvenim skupinama koje su se našle u ranjivim situacijama zbog strukturalnih ekonomskih promjena (privatizacija i komodifikacija javnih službi)« (str. 26).

Drugi dio knjige započinje poglavljem Joszefa Hegedusa Stambena privatizacija $i$ povrat oduzete imovine. Masovni otkup i povrat prethodno nacionaliziranih stanova zaoštrio je društvene konflikte zbog ukida- 
nja hibridnog statusa »kvazi-vlasničkog« (javnog) najma kojim su pojedinci bez formalnog vlasništva nad stanom uživali širok spektar prava. Također, povratom su pojedinci preko noći postajali podstanari u stanovima novih/starih vlasnika. Autor smatra da se negativne posljedice privatizacije $i$ povrata javljaju uglavnom po pitanju principa jednakosti, priuštivosti i efikasnosti, odnosno, bogaćenja jednog dijela stanara zbog niskih cijena otkupa stanova »zasluženih« u socijalizmu, drastičnog povećanja cijena stanova i troškova stanovanja u uvjetima općeg smanjenja dohotka kućanstava, te problema neadekvatnog upravljanja loše održavanim stambenim fondom.

Naziv trećeg poglavlja Wolfganga Ammana, Joszefa Hegedusa, Martina Luxa i Elisabeth Springler je Financiranje socijalnog stanovanja. Autori analiziraju pojavu novog sustava stambenog financiranja tijekom tranzicijskih procesa. Istočnoeuropski stambeni model podrazumijevao je financiranje investicija iz proračuna pod nadzorom središnjih (državnih) banaka te kreditiranje prema diktatu centralnih agencija za planiranje (str. 50). Tranzicijskom reformom drastično su smanjeni proračunski izdaci za stanovanje i novu stambenu gradnju. Ipak, autori smatraju da su »stabilno povećanje dohotka kućanstva, povoljni makroekonomski trendovi (opadajuća inflacija i kamate), pravne promjene (regulacije ovrha), natjecanje među bankama i povećavanje viška financijske štednje svjetske ekonomije vodili ubrzanom razvoju sustava hipotekarnog financiranja poslije 2000. u zemljama Srednje i Istočne Europe« (str. 52-53). Pozitivne promjene naglo su zaustavljene globalnom financijskom krizom 2008. i posljedičnom ekonomskom recesijom. Lokalne vlasti i neprofitne organizacije djelovale su s različitom razinom uspjeha po pitanju financiranja socijalnog stanovanja pa autori zaključno naglašava- ju potrebu ponovnog skretanja pažnje na socijalno stanovanje u svrhu podmirivanja stambenih potreba najranjivijih skupina.

Četvrto poglavlje Martina Luxa i Alexandra Puzanova nosi naziv Regulacija najmnina i stambene subvencije. Autori daju definiciju kontrole najamnina i njihove oblike te komparativnom analizom odabranog uzorka zemalja uočavaju mnoge nekonzistentnosti kontrole stambenih najamnina u tranzicijskim zemljama, poput privilegiranja ostataka korisnika javnog najma uz ignoriranje potreba novih nezbrinutih kućanstava. Subvencije dodijeljene kućanstvima temeljem provjere prihoda i imovine su, uz kontrolu najamnine, najpoznatiji instrument stambene politike. Autori zaključuju da je taj instrument $u$ tranzicijskom razdoblju doživio sustavnu marginalizaciju, a posljedice ovakvih trendova očitovat će se daljnjim favoriziranjem posjedovanja stana.

Peto poglavlje Joszefa Hegedusa i Nore Teller nazvano je Najmodavci socijalnih stanova $i$ upravljanje socijalnim stanovima. Autori smatraju da je prenamjena ostatka neprivatiziranog javnog (državnog) stambenog fonda iz socijalizma $u$ fond socijalnog stanovanja namijenjenog ciljanim skupinama pod novim upravljačkim vodstvom lokalnih vlasti i neprofitnih organizacija bila obilježena konfliktima i problemima. Balansiranjem imperativa fiskalnih ograničenja, povećane potražnje za socijalnim stanovanjem i osnaživanja tržišta, najmodavci socijalnih stanova neadekvatno su odgovorili na tenzije proizašle iz sukoba suprotstavljenih funkcija: upravljanja vlasništvom i socijalne misije. Autori rješenje vide u obnovi međusobne suradnje lokalnih i središnjih vlasti te neprofitnih organizacija pri čemu ističu mogućnost iskorištavanja europskih fondova.

Šesto poglavlje Catalina Berescua, Mine Petrović i Nore Teller pod nazivom 
Stambena isključenost Roma: život na rubu tiče se procjene diskursa stambenog isključenja romske populacije uz pomoć komparativne analize romskog podmirivanja stambenih potreba u tri tranzicijske zemlje: Rumunjskoj, Srbiji i Mađarskoj. Višedimenzionalno isključenje Roma je osim na individualnoj i komunalnoj, vidljivo i na institucionalnoj razini, stoga autori na temelju analiza zaključuju da postoji kontinuirana stigmatizacija Roma čije unaprjeđenje života nije prioritet nijednoj vlasti već njihova nevidljivost. Nekvalitetna gradnja socijalnih stanova, diskrepancija nacionalnih planova $\mathrm{i}$ njihove implementacije te nova getoizacija Roma urodila je nepremostivim problemima te ukazala na temeljni instrument njihovog rješavanja: socijalno uključivanje (str. 110).

U trećem dijelu knjige predstavljeni su rezultati istraživanja socijalnog stanovanja kroz 12 studija slučaja postsocijalističkih zemalja: Jozsef Hegedus, Gorana Stjepanović i Nora Teller - Bosna i Hercegovina: Granice pristupa ljudskih prava socijalnom stanovanju; Gojko Bežovan - Hrvatska: Potraga za socijalnim stanovanjem odgođena poratnom obnovom; Martin Lux - Češka: U rascjepu između općinskog $i$ socijalnog stanovanja; Anneli Kahrik i Juri Kore - Estonija: Rezidualizacija socijalnog stanovanja i novi programi, Jozsef Hegedus - Mađarska: Ideje i planovi bez političke volje; Alina Muziol-Weclawowicz - Poljska: Stari problemi i nove dileme; Wolfgang Amann, Ioan Bejan i Alexis Mundt - Rumunjska: Nacionalna agencija za stanovanje: ključni dionik u stambenoj politici; Alexandr Puzanov - Rusija: Perzistencija socijalističkog naslijeđa; Mina Petrović - Srbija: Krpljenje lokalnih opcija; Marek Hojsik - Slovačka: Na putu prema konceptu stabilnog socijalnog stanovanja; Andreja Cirman i Srna Mandič - Slovenija: Sektor socijalnog stanovanja u potrazi za identitetom te Irina Zapatrina - Ukrajina: Liste čekanja bez stanova. Tranzicijski stambeni procesi u Bosni i Hercegovini, Hrvatskoj i Srbiji bili su pod utjecajem ratnih zbivanja, socijalnih kriza te politički uvjetovane pretvorbe i privatizacije. Socijalističko nasljeđe dominantno je utjecalo na nekoherentni razvoj socijalnog stanovanja u Ukrajini, Rumunjskoj, Estoniji i Rusiji. Uzevši u obzir transformacijske prednosti i nedostatke, primjeri Slovačke, Mađarske, Slovenije, Poljske i Češke ukazuju na reforme čiji su rezultati razvoja socijalnog stanovanja bili povoljniji od ostatka zemalja iz uzorka. Ovakva podjela plodonosna je za izradu programa socijalnog stanovanja u Hrvatskoj, jer se mogu primijeniti znanja i dobre prakse srednjoeuropskih zemalja te onemogućiti razvoj regresivnih scenarija istočnoeuropskih i pojedinih susjednih zemalja. Primjerice, nedostatak podataka o socijalnom stanovanju, neodrživost kratkoročnih programa obnove porušenog stambenog fonda te zbrinjavanje izbjeglica i povratnika uz financijsku pomoć međunarodnih institucija i donatora regresivni su čimbenici Bosne i Hercegovine, a slični primjeri vidljivi su i u Srbiji u kojoj državna potpora nije izmijenila negativne trendove pa trenutno imaju najmanji udio socijalnih stanova od svih zemalja u uzorku (str. 326). Bivše sovjetske republike i Rumunjska najbolje odražavaju trend marginalizacije socijalnog stanovanja s kontradiktornom ili nepostojećom pravnom regulativom, fiktivnim programima razvoja socijalnog stanovanja, ostacima politički intonirane državne stambene skrbi te problemima priuštivosti, pristupačnosti i kvalitete stanovanja. Ako se izuzme specifični ratni kontekst, iskustva srednjoeuropskih zemalja najbliža su hrvatskim, te ih obilježavaju sljedeći problemi: nagla privatizacija i posljedični rast stambenih nejednakosti, favoriziranje posjedničkog ethosa, 
de-centralizacija upravljanja stambenim fondom i netransparentnost lokalnih vlasti, nedovoljna uloga neprofitnih stambenih organizacija, nedostatak sustavnog izvora podataka relevantnih za izradu stambenih programa, regresivne izmjene i dokidanja strategija sukladno političkim ciklusima, ilegalna gradnja i iznajmljivanje stanova, marginalizacija socijalnog stanovanja, fokus na politikama usmjerenim prema pomoći srednjim klasama, porast stambenog kreditiranja privatnih (stranih) banaka, politika štednje u razdoblju financijske krize i recesije te konačno neadekvatna politička inicijativa sustavnog stambenog zbrinjavanja uslijed nepostojanja nadležnosti EU-a zbog poštovanja načela supsidijarnosti.

Posljednje poglavlje Martina Luxa i Petra Sunege pod nazivom Nove strategije socijalnog stanovanja $u$ postsocijalističkim zemljama: djelotvornost, učinkovitost $i$ održivost jest rekapitulacija rezultata istraživanja iz knjige i kritički osvrt na stambene trendove te strategije učinkovitosti i održivosti socijalnog stanovanja postsocijalističkih zemalja s posebnim osvrtom na »privatizacijsku zamku«, »paradoks decentralizacije «, radikalnu transformaciju pravnog sustava te položaj postsocijalističkih ekonomija u svijetu globaliziranog tržišta (str. 311-312).

Dragocjenost ove knjige ne očituje se tek $\mathrm{u}$ interdisciplinarnoj sustavnoj analizi važnog, ali opetovano zanemarenog područja socijalnog stanovanja, već se s kvalitetnim istraživačkim doprinosima i analiziranim trendovima može pristupiti edukaciji donositelja odluka, neprofitnih organizacija, te akademske i ostale zainteresirane javnosti.

\section{Josip Pandžić}

Poslijediplomski doktorski studij socijalne politike doi: 10.3935/rsp.v22i2.1312

\section{MIGRACIJE I RAZVOJ HRVATSKE - PODLOGA ZA HRVATSKU MIGRACIJSKU STRATEGIJU}

\section{Vlado Puljiz, Josip Tica i Davorko Vidović (ur.)}

Zagreb: Hrvatska gospodarska komora, 2014., $300 \mathrm{str}$.

Usprkos važnosti teme, u Hrvatskoj je razmjerno malo interdisciplinarnih studija posvećenih značenju i odrednicama migracija u suvremenom društvu. Stanje se promijenilo zahvaljujući publikaciji Migracije i razvoj Hrvatske - Podloga za hrvatsku migracijsku strategiju predstavljenoj krajem 2014. Ta knjiga u izdanju Hrvatske gospodarske komore je zbornik radova uglednih hrvatskih stručnjaka s područja demografije, makroekonomije, sociologije i socijalne geografije koji nastoje usmjeriti pozornost hrvatske gospodarske, političke i stručne javnosti na važnost demografskih kretanja, migracija i ljudskog kapitala. Urednici knjige su Vlado Puljiz, Josip Tica i Davorko Vidović. Knjiga bi trebala pridonijeti unapređenju svijesti i poboljšanju znanja svih dionika u Hrvatskoj da moraju pozornost usmjeriti na temu sustavne migracijske politike koja zasad ne postoji i na potrebu izrade migracijske strategije.

U razmjerno kratkom prikazu tog štiva, dosta je teško odabrati najvažnije poruke koje govore o tako važnoj temi kao što su migracije. Ispred Gospodarske komore Luka Burilović u Riječi izdavača naglašava kako su demografska kretanja u Hrvatskoj istodobno i prepreka, ali i prilika daljnjeg gospodarskog razvoja zemlje. Imajući na umu važnost ljudskih resursa kao odredni- 